\title{
Guds frie nåde, troens frie gensvar: Frelsens betingelser hos N. F. S. Grundtvig og John Wesley
}

\section{Af Niels Henrik Gregersen}

I denne artikel sammenlignes John Wesleys (1703-1791) og N. F. S Grundtvigs (1783-1872) teologi med særligt henblik på forholdet mellem menneskets frihed og Guds nåde. For Wesley og Grundtvig gælder friheden ikke kun i politiske sammenhæng, men også i forholdet til Gud. Ifølge Wesley er menneskets frelse "konditioneret" af, at mennesket frit siger ja til Guds nåde, der kommer ethvert menneske $\mathrm{i}$ møde, såvel i kirken som uden for. Men også hos Grundtvig hører det med til "Frelsens Vilkaar", at også "det gamle menneske" siger ja til dåbens indbydelse, selv om mennesket endnu ikke blevet er genfødt ved helligånden. Forholdet mellem Guds Ja og menneskets Amen kaldes ligefrem en "Aftale" mellem Gud og menneske. Denne kontraktteoretiske baggrund for Grundtvig har været overset eller ligefrem benægtet i Grundtvig-forskningen. Ikke desto mindre er tanken om dåben som tosidet "Pagt" en integreret del af Grundtvigs kirkelige anskuelse. Den findes da også både formuleret i salmerne, i prædikenerne og på fremtrædende plads i Den christelige Børnelaerdom.

Hvad har John Wesley, metodismens fader, med Grundtvig at bestille? Umiddelbart ikke særlig meget. Wesley (1703-1791) har af gode grunde aldrig kendt Grundtvig, der levede to eller tre generationer senere. Og selv om Grundtvig har gendigtet broderen Charles Wesleys Helgen her og helgen hisset (GSV I nr. $364=D D S 573)$, spiller den metodistiske bevægelse ikke nogen større rolle i Grundtvigs ellers omfattende historiske selvplacering.

Alligevel hører John Wesley til en af de skikkelser, som Grundtvig omtaler mest positivt blandt de efterreformatoriske skikkelser i den engelske kirke. I nærværende artikel skal jeg forsøge at påvise en lang række fællestræk mellem Grundtvig og Wesley. Min tese vil være, at Wesleys og Grundtvigs teologier kan opfattes som to distinkte, men parallelle forsøg på at bidrage til reformationens modernisering. Begge ønsker at sige "nåden alene" og "troen alene" i forlængelse af den lutherske reformation. Men begge afviser den dobbelte prædestinationslære, samt den overleverede augustinske nådesteologi, der siger, at nåden er uimodståelig (gratia irresistibilis) for den, som Helligånden har udvalgt. På hver deres måde gør Wesley og Grundtvig gældende, at nåden ikke tvinger, men inviterer til menneskets frie 
tilslutning. For mennesket er skabt til frihed, og Gud vil menneskets frie gensvar på Guds nåde.

Forskellen er, at mens Wesley udarbejder en frelseslære, der bygger på et samvirke mellem Guds forberedende nåde og menneskets frie overbevisning, udbygger Grundtvig i stedet skabelseslæren. Ifølge Grundtvig har også "det gamle menneske" (dvs. det menneske der endnu ikke er blevet fornyet af Helligånden) mulighed for at forsage løgnens Fader og dermed sige ja til Guds indbydelse ved dåben. Dåben betegnes af Grundtvig som en pagt eller "Aftale", og en aftale eller kontrakt fordrer nu engang to parter, der hver gør sit. Wesley talte her direkte om frelsens "betingethed" af menneskets frie tilslutning, hvad der førte ham ind $\mathrm{i}$ frontalt opgør med den reformatoriske nådeslære. Et sådant direkte opgør findes ikke hos Grundtvig. Men også hos Grundtvig findes der frelseskonditionalistiske motiver, som har været overset eller rent ud sagt benægtet $\mathrm{i}$ forskningen. For også Grundtvig hævder, at der er knyttet bestemte "Vilkår" til troens pagt, som mennesket må sige ja til. Sådanne formuleringer af en tosidethed mellem Gud og menneske er ikke blot tilfældige, men er bygget ind $\mathrm{i}$ selve den kirkelige anskuelses struktur. De frelseskonditionalistiske motiver findes således $\mathrm{i}$ dåbsteologien såvel i Den christelige Børnelardom som i salmerne og i prædikenerne. De tydelige spor af en moderne kontrakttænkning findes med andre ord i selve hjertet af Grundtvigs teologi. Guds nåde er for Grundtvig et "Tilbud", der vil modtages i frihed. Friheden skal derfor ikke kun gælde i borgerlige sager, men også i åndelige sager, det vil sige i gudsforholdet.

\section{Grundtvig om Wesley}

Hvad siger Grundtvig selv om Wesley? I Kort Begreb af Verdens Krønike i Sammenhoeng fra 1812 giver Grundtvig sin måske mest udførlige vurdering af den engelske kirke, og vurderingen falder alt andet end positivt ud: I England blev det ifølge Grundtvig kun til "den halve, sig selv modsigende Reformation", og der herskede en stadig strid mellem "den kalvinske Ubændighed", der trivedes jæunsides med "egennyttig Vantro". Går vi frem til 1700-tallet får kvækerne og metodisterne at vide, at de er sværmeriske pietister. I forlængelse heraf har danske Grundtvig-forskere gerne modstillet Grundtvigs store Ja til Livet med metodismens pietistiske verdensforagt og himmellængsel. ${ }^{2}$ Men dels må man spørge, om denne læsning ikke bygger på en karikeret forståelse af Wesley, og dels kommer man ikke bort fra, at netop John Wesley făr en særstilling hos Grundtvig:

Det gik dem [brødrene Vesley] og deres Staldbroder Vhitefield, som det maa gaa alle Pietister, de bleve Sværmere, foregave Aabenbaringer 
og ventede paa at blive syndeløse herneden. Imidlertid føiede Gud det saa, at Johan Vesley paa Veien til Amerika blev kendt med nogle Hernhutter, af hvem han lærte, hvad paa den Tid synes at have været aldeles glemt i England, at det er ved Troen paa Jesus vi blive retfærdige. Vel holdt han fast paa det strænge Levnet, men det var maaske nødvendigt, naar han ei vilde opgive Dyden, og hans Skilsmisse fra Zinzendorfs engelske Tilhængere, der, som begribeligt er, i Ugudelighed langt overgik de tyske, beviser at sand Christendom laa ham paa Hierte. Mærkeligt er det, at fra den Stund, da Vesley vandt Tro paa Retfærdiggørelsen ved Jesum, aftog hans Sværmeri daglig: han forkastede sine Aabenbaringsgriller, nærmede sig Luthers Mening om Naadevalget, og dannede sin Menighed med Prædiken og Sang, efter luthersk Mønster. ${ }^{3}$

Tydeligvis ser Grundtvig her Wesley som en teolog, der har fundet hvile i Luthers retfærdiggørelseslære og etableret menigheder efter luthersk forbillede. Hermed henviser Grundtvig sandsynligvis til, at John Wesley i 1738 hørte Luthers fortale til Romerbrevet blive læst op, hvad der førte til en afgørende vending i hans kristendomsopfattelse. Hvad Grundtvig derimod ikke nævner er, at Wesley senere lagde stærk afstand til Luther, fordi han ikke hos Luther fandt en tilstrækkelig lære om menneskets helliggørelse. Grundtvigs henvisning til, at Wesley nærmede sig "Luthers Mening om Naadevalget", kan også undre, eftersom Luther livet igennem fastholdt den augustinske lære om den dobbelte prædestination (ifølge hvilken Gud udvælger nogen til frelse og andre til fortabelse). Grundtvig må enten have forstået Luthers teologi som et opgør med hele den mørke side i Augustins kristendomsopfattelse (hvad der næppe er historisk korrekt) eller også har han med "Luthers Mening" tænkt på den senere lutheranisme, som i Konkordieformlen fra 1577 hævdede, at Gud $ø$ nker at frelse alle mennesker. Hermed bliver prædestinationen netop til et "Naadevalg".

Uanset eventuelle uskarpheder i Grundtvigs Lutherbillede er den særstilling, som Grundtvig tildeler John Wesley, bemærkelsesværdig. Herhjemme har allerede Hal Koch gjort opmærksom på dette forhold. Nyere forskning har da også vist, at der i det mindste er mulighed for at opspore en række analogier mellem Wesley og Grundtvig. Den engelsk-amerikanske teolog Geoffrey Wainwright har således påvist lighed mellem Wesley og Grundtvig i synet på fornuft, erfaring, skrift og tradition - de fire grundpiller, som den metodiske bevægelse i nyere tid er blevet identificeret med. ${ }^{4}$ Spørgsmålet er imidlertid, om man kan komme et skridt videre end de blotte analogier. Netop i synet på nåden og den frie vilje er der tale om substantielle teologiske ligheder mellem Wesley og Grundtvig, både hvad angår problem- 
stilling og løsningsforslag. Begge ønsker at formulere en teologi, der kan tale om Guds nåde på en sådan måde, at mennesket af Gud tilskyndes til at sige troens Ja. Den overleverede lære om den uimodståelige nåde transformeres til en lære om den overtalende nåde.

\section{Reformationens modernisering}

Først nogle teologihistoriske grunde til at bringe Wesley og Grundtvig sammen. De forstod sig begge som reformatoriske teologer, men vel at mærke placeret $i$ en ny tidsalder, hvor menneskets frihed var kommet $i$ centrum. Friheden hører menneskelivet til, både for den kristne og den ikke-kristne, men først Guds nåde kan realisere den frihed, som mennesket på forhånd er skabt til af Gud. Selv om Wesley og navnlig Grundtvig var rationalitetskritikere, indoptog de hver på deres måde oplysningstidens ideal om den myndige kristendom i sig: Det fremhævedes, at "Troen nødvendig maa være en fri Sag, fordi det er en Hjærte-Sag", 5 som Grundtvig udtrykte det. Den lutherske reformation måtte fortsættes og bringes til sin fuldendelse, hvad den altså ikke blev i 1500-tallet.

Der er også biografiske lighedspunkter. På ægte pietistisk vis oplevede både Wesley og Grundtvig omvendelseserfaringer, i begge tilfælde knyttet til genopdagelsen af Luthers retfærdiggørelseslære. Wesley kunne ligefrem sætte dag og klokkeslæt på sin omvendelseserfaring d. 24. maj 1738 "kl. 8 3/4", mens han hørte Luthers fortale til Romerbrevet læst højt, mens Grundtvigs lutherske vækkelse først brød igennem efter en langvarig forudgående depression i 1810-11. Men begge måtte snart efter distancere sig fra Luther. Wesley så sig nødsaget til at bryde med Luthers retfærdiggørelseslære, fordi denne ifølge Wesley ikke gav plads til den helliggørelseslære, der skulle blive metodismens kendetegn. ${ }^{6}$ Wesleys idé om den kristnes mulighed for perfektion delte Grundtvig bestemt ikke. ${ }^{7}$ Her som ellers vedblev Luther med at være et pejlemærke for Grundtvig. Luther indvarslede en ny tid, men reformationsbevægelsen skulle fortsættes ind i en tid, hvor kirkefolket er blevet myndigt og må frigøres fra den statskirkelige uniformering. Både Wesley og Grundtvig skabte da også selvstændige menighedsdannelser. Og ligesom Wesley til det sidste forblev tro over for Church of England, forlod Grundtvig aldrig den evangelisklutherske kirke i Danmark (efter 1849 Folkekirken), selv om han ofte truede med at gøre det. ${ }^{8}$

Det er derfor sikkert mere end et tilfælde, at hverken Wesley eller Grundtvig forstod sig som fagteologer i snæver forstand. Begge fandt de deres i virke i det offentlige liv og gjorde deres teologi gældende dér. Albert C. Outler har med rette betegnet Wesley som 'folktheologian' og peget på, at Wesley bevidst rettede sine teologiske 
læreprædikener til almindelige mennesker. I sit forord til Sermons on Several Occasions fra 1746 siger Wesley det selv: "I design plain words for plain people ... My design is, in some sense, to forget all that I have ever read." Med sin ligefremme stil og sin appel til skrift, erfaring og common sense må Wesley endda siges at være en betydelig mere folkelig teolog end den sprænglærde Grundtvig, der aldrig helt kunne glemme, hvad han havde læst. Mens Grundtvigs prosa er både svunget og tungt læsset, skriver Wesley hårdt og pågående, $\mathrm{i}$ en direkte henvendelse til menigmand.

\section{Frelsesuniversalisme og konditionalisme}

Men der er også et substantielt teologisk slægtskab mellem Wesley og Grundtvig. Intetsteds kommer dette tydeligere til udtryk end i nådeslæren. Begge forstår Guds nåde som universel i betydningen: rettet til alle mennesker. Af samme grund afvises den dobbelte prædestinationslære, som indebærer, at Gud også har forudbestemt nogle til fortabelse. Alligevel var hverken Wesley eller Grundtvig tilhængere af apokatastasis-læren, det vil sige tanken om alles frelse. Ved tidernes ende vil det komme til en dobbelt udgang, hvor frelste og fortabte vil blive skilt som fårene fra bukkene. Der findes en fortabelsens æt, der vil gå fortabt. Ikke fordi nåden ikke tilbydes alle fra Gud, men som et resultat af, at ikke alle vil tage imod Guds nåde. For ingen kan tvinges ind i Guds Rige.

Hvad angår synet på nåden og den frie vilje, kunne man sige, at Wesley og Grundtvig repræsenterer to forskellige versioner af den position, der i den engelsksprogede fagterminologi kaldes frelsesuniversalistisk konditionalisme. Det vil sige, at Gud vil alles frelse, men samtidig er frelsen betinget - dog ikke af menneskets gerninger over for Gud, men af troens frie gensvar til Guds frie nåde. Mennesket skal selv sige sit ja til Guds store Ja.

Her viser der sig imidlertid en afgørende forskel mellem Wesley og Grundtvig. Som enhver anden moderne vækkelsesforkynder var Wesley af den overbevisning, at mennesket skal tro på Gud her i livet. Ellers er det uhjælpeligt for sent. Samtidig var det for Wesley et problem, at evangeliets forkyndelse ikke når ud til alle mennesker på jordkloden, ligesom Kristus naturligvis ikke blev klart forkyndt før Kristi fødsel. Derfor udarbejdede Wesley en omfattende lære om Guds prevenient grace. Denne forudgående eller imødekommende nåde bliver igen og igen tilbudt ethvert menneske i dets livsløb. Til stadighed overtaler Gud mennesket til at hengive sig til Gud i tro og tillid - også uden for kristendommens kulturkreds. Wesleys hovedtekst 
er her Johannes-prologens ord om, at Kristus er "lyset, det sande lys, der oplyser ethvert menneske" (Joh 1,9). Den forudgående nåde er således identisk med den nåde $\mathrm{og}$ det lys, som kom til verden med Kristus. "Han kom til sit eget", men hans egne tog ikke altid imod ham (Joh 1,11). Menneskets frihed skal ikke forstås som en naturlig udrustning i mennesket, men er omgærdet af Guds imødekommende nåde, der til stadighed søger det faldne menneske og vil redde det.

Grundtvig placerer i første omgang friheden et andet sted: ikke i frelseslæren, men i skabelseslæren. Heri viderefører han den lutherske tradition, samtidig med at han korrigerer den. Når Grundtvig taler om friheden for både Loke og Thor, tænker han først og fremmest på den dennesidige frihed til at forvalte skaberværket i overensstemmelse med ret, rimelighed og ånd. Skabelsens liv rummer ikke den frelsende nåde, lige så lidt som folkeånden umiddelbart indeholder Helligånden. Så langt følger Grundtvig den lutherske sondring mellem de "to regimenter", det verdslige og det åndelige. Men skabelsens og frelsens orden står ikke blot ved siden af hinanden som to parallelle verdener. Tværtimod er det Grundtvigs gennemgående tanke, at ligesom mennesket er skabt i Guds billede og fortsat er sandhedssøgende og har evne til kærlighed, således er folkelivet til stadighed det kristne livs "Forudsætning og Betingelse". ${ }^{10}$ Men først ved "Badet og Bordet" møder mennesket den nåde, som alene kan frigøre mennesket og skænke det evigt liv. Dette er centrum i Grundtvigs kirkelige anskuelse.

Alligevel kan Grundtvig som universalhistorisk tænker ikke stille sig tilfreds med den sakramentale løsning, som hans kirkelige anskuelse er udtryk for. For at afbøde den frelsespartikularisme, som ligger i den gamle lære om, at alene den døbte bliver frelst, ${ }^{11}$ udformede Grundtvig som bekendt sin vision om, at alle mennesker vil få tilbudt nådens ord $\mathrm{i}$ dødsriget. Grundtvigs hovedtekst er her foruden trosbekendelsen - 1 Pet 3,18-22, hvori der fortælles, at Kristus tog ned til Dødsriget for at prædike evangeliet for de ulydige ånder, der blev holdt i fængsel dér ( $V U$ VI, 37 f.) Grundtvig og den senere grundtvigianisme udviklede således tanken om "den anden chance", som tilbødes efter døden. Ganske vist er der for Grundtvig ikke nogen frelse i noget andet navn end i Kristus. Men den Kristus, som vil alles frelse, vil på den yderste dag åbenbare sig for alle på klarhedens og utvetydighedens betingelser. Kun den, som dér vil sige nej til KristusLyset, hører til fortabelsens æt.

Wesley og Grundtvig deler således den opfattelse, at frelsen ikke kan finde sted uden en ny pagt mellem Gud og menneske. Pagtstanken indebærer allerede logisk set tanken om en tosidet relation mellem Gud og mennesket, mellem Guds nåde og menneskets frihed. Hos Wesley udformes dette i en udtrykkelig nytolkning af nådeslæren. ${ }^{12}$ Men hvad man ofte har overset er, at også Grundtvig i Den christelige 
Børnelaerdom taler om troen og bekendelsen i kontraktuelle termer. Forskellen er da den, at mens Wesley udarbejder en lære om et samarbejde mellem Guds nåde og den, som allerede er genfødt i troen, lægger Grundtvig vægten på, at Kristus ved dåbspagtens indgåelse ikke forlanger mere end det naturlige, men faldne menneske i sig selv er i stand til at realisere $i$ form af en ærlig sandhedssøgen og en ærlig vilje til at møde Gud ( $V U$ VI, 20). Forsagelsen af Djævelen som løgnens fader bestemmer Grundtvig som en "Forudsatning" for Guds antagelse af mennesket før genfødelsen i dåben og før fornyelsen i nadveren ( $V U$ VI, 23). Forsagelsen bestemmes som dåbspagtens "Vilkaar" (ibid., 21 f.), mens dåbspagten betegnes som en "Aftale" mellem Gud og menneske (ibid., 40). Kontrakten mellem Gud og menneske er altså tosidig, ikke ensidig. Alligevel er den gensidige relation asymmetrisk, for så vidt som mennesket ikke har andet at give til Gud end troens frie gensvar til Herrens indbydende Ord. Alle Guds gaver "rækkes af Hans [Guds] fri Naade, og kan kun blive deres, der med fri Tro og Taknemmelighed modtager dem af Herrens Haand" (ibid., 47; Grundtvigs understregninger). Grundtvig taler altså her helt ligefremt om frelsens vilkår, forstået som de faktiske vilkår, der nu engang er dåbens forudsætning. ${ }^{13}$

Hos Wesley finder vi en udtrykkelig lære om den universalistiske konditionalisme. Wesley gjorde derfor radikalt op med den augustinsk-reformatoriske lære om den "uimodståelige nåde" (gratia irresistibilis). Jeg har imidlertid ikke fundet noget sted, hvor Grundtvig på samme frontale måde afviser denne lære. Tværtimod kan han - ikke mindst i salmerne - besynge nådens kraft ved Helligånden. Derimod er der flere steder, hvor han klart formulerer pagtens tosidighed uden at præcisere, hvad forholdet er mellem Guds handlen og menneskets handlen, når først nåden har slået rod. Om Grundtvig har udviklet et klart syn på menneskets frihed i forhold til Gud, når nåden er blevet givet, vil kræve en større undersøgelse, som endnu venter på at blive gennemført. Hvad jeg her alene vil pege på er, at de konditionalistiske motiver rent faktisk findes hos Grundtvig, endda som et integreret element $i$ hans kirkelige anskuelse.

Imidlertid kan hverken Wesley eller Grundtvig beskyldes for at være pelagianere, selv om de gør oprør mod den augustinskreformatoriske forestilling om, at Gud skænker sin nåde til nogen, men ikke til andre. Guds "Naadevalg" gælder ethvert menneske, herom er Wesley og Grundtvig enige. Dermed befinder både Wesley og Grundtvig sig i et henholdsvis udtalt og uudtalt opgør med den dobbelte prædestinationslære, som reformatorerne havde overtaget fra vestkirkens normgivende teolog, Augustin. 
Luther, Calvin og den augustinske prodestinationslore: en problemskitse

Grundtrækkene i den augustinske myte om menneskets fald og frelse er følgende: Oprindeligt var Adam og Eva skabt gode og retfærdige. Men samtidig havde de fået frihedens tvetydige gave. Denne frihed blev brugt til at synde. Men gennem Adams og Evas syndefald er synden nedarvet til alle mennesker, og alle mennesker er dermed kommet ind under Guds vrede og fordømmelse. Guds vrede er retfærdig, fordi alle mennesker "har syndet i Adam" og derfor fortjener den evige fortabelse. Men samtidig er vreden uundgåelig, fordi Adams og Evas børn på grund af arvesynden ikke længere er i stand til at rette viljen mod Gud.

Guds nåde bliver derfor af Augustin forstået som Guds nye og uselvfølgelige handling, der bryder med arvesynden og ved Helligåndens kraft sætter mennesket $\mathrm{i}$ stand til atter at fæste lid til Gud. Imidlertid gives nådens gave ikke til alle. Nåden gives kun til dem, som Gud forud for skaberværket har besluttet sig for at frelse, ikke mindst for at udfylde det hul, der opstod i himmelverdenen, da mørkets engle fulgte Satan og faldt med ham. Resten af menneskeheden hører derimod til fortabelsens masse (massa perditionis). ${ }^{14}$

Således det augustinske historiesyn, der har fungeret som en basso continuo i vestkirkens tradition fra Augustin over middelalderen frem til Luther og Calvin. Det er et kendetegn for Wesleys og Grundvigs indsats, at de på hver deres måde demonterer denne augustinske grundfortælling, samtidig med at de redder den pointe fra arvesyndslæren, at et menneske ikke af sig selv kan beslutte sig til at leve $\mathrm{i}$ troens tillid, $\mathrm{i}$ håbets åbenhed og realisere kærligheden $\mathrm{i}$ dens fulde omfang. Men Gud bejler til stadighed til ethvert menneske, om det dog ikke vil hengive sig til Gud i tro, håb og kærlighed.

For Luther var derimod selve tanken om en fri vilje, der ved egen kraft kunne sige ja eller nej til nåden, et tankemæssigt misfoster. Argumenterne herfor fremlagde Luther i skriftet om Den traelbundne vilje fra 1525: For det første er et menneskes vilje erfaringsmæssigt aldrig fri, fordi mennesket altid er fuldt opsat på at ville, hvad mennesket nu har gang i. For det andet sidder arvesynden så dybt i menneskets vilje, at denne skal fornys ved Helligåndens kraft, hvis mennesket overhovedet skal kunne sige ja til nådens Ja. Lader man som om, at menneskets vilje er intakt, ser man bort fra den realitet, at det faldne mennesket aldrig vil sige ja til nåden - og derfor heller ikke kan det. Luther mente derfor, at menneskets evige frelse ville blive en aldeles usikker sag, hvis den skulle bero på menneskets eget ja og amen til Gud. Mennesket kan kun være vis på sin frelse, hvis det er 
Gud, der står bag også menneskets ja til Gud. Derfor hævdede Luther, at Gud i sit forsyn "både beslutter og bevirker alting i kraft af sin uforanderlige og evige usvigelige vilje" (WA 18, 615). Dette gjaldt ifølge Luther for alle forhold, både små og store, men så meget mere gælder nødvendighedens logik i spørgsmålet om den evige frelse. Før alle tider har Gud besluttet at frelse nogen af kærlighed, men også at forbande andre ved sit evige had:

Gud elsker og hader med sit evige og uforanderlige væsen... For i Guds forhold til menneskene er Hans kærlighed evig og uforanderlig; evigt er hans had, førend verden blev til, ikke blot førend en fri menneskelig selvbestemmelse gik i gang med at gøre noget, som fortjener gengældelse (WA 18, 724-25). ${ }^{15}$

Luther tilslutter sig således den såkaldte dobbelte prædestinationslære, som Augustin havde udviklet i sit opgør med Pelagius. Ganske vist benyttede Luther lige så lidt som Augustin selve udtrykket "den dobbelte prædestination" (praedestinatio gemina). Men han lærte den både $\mathrm{i}$ teori og praksis. Prædestinationslæren var for Luther ikke blot en teologisk efterrationalisering, det vil sige formuleret på basis af, om mennesket i sit livsforløb tager imod Guds tilgivelse eller ej. Det er omvendt: det er Guds forudbestemmelse forud for alle tider, der bestemmer, om et menneske bliver retfærdiggjort $\mathrm{i}$ tiden ved at nære tillid til evangeliets ord. Retfærdiggørelsen i tiden er et resultat af den evige udvælgelse, ikke omvendt. På samme måde er menneskets forkastelse af Guds Ord et resultat af Guds evige fordømmelse, og ikke omvendt. ${ }^{16}$ For så vidt må både Augustins, Luthers og Calvins retfærdiggørelseslære bestemmes som supralapsarisk (dvs. bestemt "forud for faldet") og ikke som infralapsarisk (dvs. bestemt af menneskets frie gensvar i tro eller vantro "efter faldet"). Det er derfor kun naturligt, at både Luther og Calvin tolker fortællingen om Esau og Jakob (1 Mos 25) og om den forhærdede Farao (2 Mos 5-11) som eksempler på Guds evige udvælgelse af Jakob til frelse, og af Esau og Farao til evig fortabelse.

Der er grund til at fremhæve disse historiske sagforhold her, fordi den efterfølgende lutherdom afviste den dobbelte prædestinationslære, og i stedet holdt sig til Luthers pastoralt orienterede teologi. Det menneske, der er i nød, skal nemlig ifølge Luther ikke bekymre sig om Guds skjulte og evige vilje, men alene holde sig til Guds åbenbaring i Kristus. Frelsen afhænger af ubetingetheden i Guds frelsesløfte, som er uafhængigt af menneskets vilje. Denne tankestreng finder vi udtrykt mange steder hos Luther, ikke mindst i det lille skrift, En sermon om forberedelsen til at dø fra 1519 (WA 2, 685-92). Her siger Luther, at det ikke nytter at spekulere over himmel og helvede, for det fører blot 
til tvivl og mistrøstighed. I stedet skal man holde sig til de "sikre tegn", som Gud har givet mennesket i sakramenterne og i evangeliets ord: "Den, som således pukker på sakramenterne og støtter sig til dem, han skal nok vise sig at være udvalgt og forudbestemt, uden at han selv bekymrer sig derfor og gør sig møje dermed". ${ }^{17}$

Den praktiske side henholdt gammellutheranerne sig til, da de i Konkordieformlen fra 1577 gjorde gældende, at mennesket skal afholde sig fra at udgrunde Guds skjulte vilje og i stedet holde sig til Guds åbenbarede Ord i Kristus. Ifølge evangeliet er Guds frelsesvilje universel, idet frelsens tilbud er rettet til alle og enhver. "Faderen vil, at alle mennesker skal høre dette budskab og komme til Kristus, og ifølge hans eget ord vil Kristus ikke vende dem bort fra sig: 'Den, som kommer til mig, vil jeg aldrig støde bort'"(Joh 6,37); mennesket skal derfor ikke opdigte en splittet vilje i Guds skjulte natur; og ingen har ret til at drage den slutning af fortællingen om Farao og Esau, at "Gud ikke har ønsket at skænke Farao eller andre mennesker frelse, men i stedet har forudbestemt dem til evig fordømmelse i sin hemmelige rådslutning, så de ikke kunne eller ville blive frelst". ${ }^{18}$ Gud er aldrig kilde til fortabelsen; det er kun Djævelen og mennesket selv.

Denne tolkning af Luther fik afgørende betydning for lutherdommens selvforståelse. Nu blev den dobbelte prædestinationslære (som ret beset også var Luthers) identificeret som en særlig 'calvinsk' lære, som man ikke var forpligtet på, men gerne kunne lægge afstand til.

Dette var netop, hvad Wesley og Grundtvig hver på deres måde gjorde. Kritikken af den dobbelte prædestinationslære og af den skrækindjagende tanke om Guds evige had banede dermed vejen for en modernisering af den reformatoriske teologi. Reformationens sande lys kunne kun realiseres ved at bortretouchere de sider af Luthers teologi, som var forankret i augustinismens dystre gudslære. Luthers lære om den skjulte tvetydige Gud måtte vige plads for åbenbaringens Gud, der havde givet sig til kende som kærligheden. Gud tvinger ikke mennesket, men lokker troens frie gensvar frem.

Wesley udarbejdede på dette punkt tanken om Guds overtalelse af mennesket, der udgør et bevidst alternativ til den augustinskreformatoriske tradition. Grundtvigs selvstændighed i forhold til den augustinsk-lutherske tradition markerer sig ikke i et tilsvarende åbent opgør med Augustin, men udtrykker sig derimod i hans egenartede brug af den augustinske terminologi, samt i hans egne udvidelser af den lutherske tradition. I flere af Grundtvigs salmer finder vi således tanken om den Gud, der bejler til menneskets gunst og som aldrig hører op med at række mennesket sin hånd. Lad os derfor begynde med det lys, som salmedigtningen kaster over problemstillingen. 


\section{Lovsangen om Guds Nåde til alles frelse}

Mens John Wesley var den store organisator, forkynder og teolog, var lillebroderen Charles Wesley (1707-1788) metodismens store salmedigter. I en salme fra 1741, O-all redeeming Lord finder vi et gennemgribende opgør med "the horrible decree", dvs. den augustinske lære om den dobbelte prædestination:

1.

O all-redeeming Lord,

Thy kindness I record:

Me Thy kindness hath allured,

Call'd, and drawn me from above;

Sweetly am I thus assured

Of Thy everlasting love.

2.

But is Thy grace less free

For others than for me?

Lord, I have not learn'd Thee so;

Good to every man Thou art,

Free as air Thy mercies flow;

So I feel it in my heart.

3.

Thee every soul may find

Loving to all mankind;

All have once Thy drawings proved,

Every soul may say, with me,

Me the Friend of sinners loved,

Loved from all eternity.

4.

Before His name I knew

Me to Himself He drew,

My unconscious heart inclined

To pursue some good unknown;

Happiness I long'd to find, Happiness is God alone.

5.

God is the thing I sought,

But then I knew it not:

Who shall show me any good?

(With the many still I cried)

Rest was only in Thy blood,

Who for me, for all, hast died. 
6.

The world's Desire and Hope

For this was lifted up;

Lord, Thou didst hereby engage

To draw all men unto Thee,

All in every place and age:

Grace for all mankind is free!

7.

The Spirit of Thy love

With every soul hath strove;

Every fallen soul of man

May recover from his fall,

See the Lamb for sinners slain,

Feel that He hath died for all.

8.

Thou dost not mock our race

With insufficient grace;

Thou hast reprobated none,

Thou from Pharaoh's blood art free;

Thou didst once for all atone

Judas, Esay, Cain, and me. ${ }^{19}$

Charles Wesleys begrundelse for Guds kærlighed til alle skabninger er kristologisk, men karakteristisk nok udformet i to skridt. I de første tre strofer viser Charles Wesley hen til Guds venlighed (kindness), som har kaldet og tiltrukket sig salmisten fra forste færd. Guds nådehandlinger (mercies) flyder lige så frit som luften i skaberværket, og det er netop ud fra hjertets møde med Guds tiltrækkende kærlighed, som kommer mennesket i møde i livet selv, at salmisten opdager, at Guds nåde ikke er for ham selv alene: "Enhver sjæl kan sige, sammen med mig: / Mig har syndernes ven elsket / elsket fra evighed af" (strofe 3). I de næste to strofer beskrives sammenhængen mellem denne imødekommende kærlighed, som salmisten har mødt før han kendte Kristi navn, og den åbenbarede kærlighed, som han $n u$ har mødt i Kristi kors. Ubevidst har vi søgt hen imod den ukendte godhed, som er Guds (strofe 4). Men først i Kristi blod finder det urolige hjerte hvile. Ligesom den kosmisk dragende Kristus er for alle, således er også Jesu blod udgydt for alle: "Hvilen var kun i dit blod / du som døde for mig, for alle" (strofe 5). Derfor er nåden nu fri og tilgængelig for alle, som det konkluderes i salmens tre sidste strofer. Gud har ikke kun skænket en utilstrækkelig nåde, det vil sige en skabelsesnåde uden frelsesnåde. Gud har aldrig forkastet nogen. Tværtimod står vi som syndere lige over for den Gud, der har forsonet sig med alle syndere ved Kristi blod: "Du har én gang for alle forsonet dig / med Judas, Esau, Kain - og mig" (strofe 8). 
Charles Wesley vækker her genklangen af en lang række augustinske temaer, samtidig med at han giver alle begreber en ny mening. Gud er jo netop det højeste gode (summum bonum), hvad Augustin ikke blev træt af at gentage. Og henvisningen til det urolige hjerte citerer direkte Augustins Bekendelser: "Mit hjerte er uroligt, indtil det finder hvile i dig". Men hjertet, tilføjer Charles Wesley nu, kan kun blive roligt, hvis Gud på korset er død for alle mennesker. Hvis ikke der er frelse for brodermorderen Kain, for den letsindige Esau og for forræderen Judas, hvordan kan jeg så være sikker på min frelse?

I Han som på jorden bejler (DDS 479, 2003-udgaven) tager Grundtvig et lignende udgangspunkt $\mathrm{i}$ den bejlende nåde. Gud vil besegle troens himmelske pagt, "når vi kun vil". Dette lille konditionalistiske forbehold finder vi karakteristisk nok i en salme, som Grundtvig har skrevet ved en konfirmation, hvor det drejer sig om bekræftelsen af dåbens bekendelse. Salmen er således en forkortet udgave af "Velkommen, Morgenrøde" (GSV III, 219), der oprindelig var skrevet til brug i Vartov d. 23. april 1843, da Grundtvigs egen datter, Meta, skulle konfirmeres. ${ }^{20}$ Guds Ånd prises her som "KraftBeviset paa Daabens Gyldighed", og konfirmanden ser nu tilbage på dåbens førbevidste barneparadis og kan takke for, at "Vort Sjælebad i Livets Flod, / Guds Naade være priset, / Sin Prøve godt bestod!" (strofe 2). Der er altså ingen tvivl om Guds nådes prioritet, men det antydes dog også, at Guds nåde skal stå sin prøve i den troendes liv. Bærende for troens liv er Guds indbydelse; men en nødvendig betingelse er også menneskets ja til Herrens indbydelse ved dåben. Det er i denne sammenhæng, at vi finder formuleringer som disse:

Han, som paa Jorden beiler

Til Troskab uden Svig,

Naar kun vi vil, beseigler

Vor Pagt om Himmerig;

Han døber med den Helligaand,

Paa Ord, som aldrig feiler

Han rakker os sin Haand!

(GSV III, 219, 3 =DDS 2003-udgaven nr. 479, 1; mine understr.).

Det skal bemærkes, at troen som frelsens betingelse ikke fremstilles som en selvstændig trosbeslutning på afstand af Gud. Det er tværtimod en bekendelseshandling, der kaldes frem ved dåben, hvor den levende Herre selv er til stede. Den levende Kristus er til stede i det Ord, der allerførst gør troen mulig ved i tilspørgslens form at indbyde til tro og som siden hen fremelsker troen. Men alt sammen betinget af et "naar kun vi vil". Atter engang tager Grundtvig et sakramentalt 
udgangspunkt i menighedens fundamentale erfaring af at være døbt. At være døbt betyder jo netop på forhånd at vide sig grebet af Guds nåde. Derfor kan Grundtvig også her indarbejde tanken om, at Guds Ord "aldrig feiler". Isoleret kunne dette tolkes som en lære om den uimodståelige nåde. Men når Kristus og Helligånden netop ikke fejler, skyldes det i strofens sammenhæng, at Gud bliver ved med at række os sin hånd. Grundtvig benytter her en metafor, som $\mathrm{i}$ sig selv forudsætter, at der skal tages imod den hånd, der rækkes. Helligåndens ufejlbarlighed består ikke $\mathrm{i}$ dens ydre voldsomhed, men i den overbevisning, som Ånden er i stand til at skabe hos modtageren.

Ligesom Wesley overskrider også Grundtvig menighedens perspektiv i sin lovsang. Fra den sakramentale midte i dåb og nadver og bibel (strofe 1-3) flyder salmen over i besyngelse af Guds magt til at frelse ethvert menneske på jorden, der på jorden var ham tro, så der til sidst skal lyde et himmelsk hav af toner, der lovsynger Guds nåde:

Den Haand hvert Hoved kroner

Med Evighedens Guld,

Som Jesus, vor Forsoner,

Paa Jord var tro og huld;

Med Frydesang der skabes da

Et Hav af Himmeltoner,

Et fuldt Halleluja! (GSV III, 219, 6; mine undetstr.).

Til forskel fra Charles Wesley benytter Grundtvig ikke sin salme til at artikulere teologiske uenigheder med den augustinsk-reformatoriske lære om den dobbelte prædestination. I stedet bruger Grundtvig stiltiende arven fra Augustin og Luther til at formulere en lære om "Naadevalget" (US 3, 309), som ret beset hverken er Augustins eller Luthers. Guds vilje og evne til at krone hvert menneske postuleres ikke som en teologisk læremening, man kan sige ja eller nej til, men som en indsigt, der besynges ud fra menighedens midte i dåbens ord.

\section{Frelseskonditionalismen hos Wesley}

Fra salmerne bevæger vi os nu ind i de teologiske tekster, hvori Wesley og Grundtvig hver for sig fremlægger deres teologi i mere prosaisk form. Vi begynder med John Wesleys udvælgelses- og nådeslære.

Brødrene Wesleys opgør med prædestinationslæren skulle vise sig at give anledning til strid inden for den unge metodistiske bevægelse. George Whitefield og andre metodister fastholdt den calvinske nådeslære, mens både Charles og John Wesley offentligt fremstod som tilhængere af det alternativ til den dobbelte prædestination, som Jacob Arminius (1559-1609) er ophavsmand til. Arminianerne eller 
remonstranterne havde i 1610 gjort følgende fem teser gældende over for den herskende hollandske calvinisme: (1) Prædestinationen betegner den guddommelige hensigt at frelse alle, som tror, og at fordømme alle, som afviser evangeliet. (2) Kristus døde for alle. (3) Nåden er nødvendig, hvis det faldne menneske skal vælge det gode og komme til tro. (4) Guds forudgående og efterfølgende nåde kan afvises af mennesket, og (5) Også den troende har brug for Guds fortsatte nåde for at kunne forblive i nåden.

John Wesley har selv formuleret en lille apologi for arminianismen. ${ }^{21}$ Wesley gør heri gældende, at den arminianske lære er en fuldt ortodoks lære. Arminianerne og calvinisterne er nemlig enige om både arvesyndslæren og retfærdiggørelsen ved tro alene. Hvad de er uenige om, er tre sammenhængende forhold: calvinisterne lærer, at Guds prædestination er absolut, at Guds nåde er lige så uimodståelig som et lynnedslag, og at en sandt troende aldrig nogensinde kan falde fra troen. Arminianerne lærer derimod for det første, at Guds prædestination er betinget ("conditioned"), eftersom Kristus er død for alles synder. For det andet lærer arminianerne, at selv om der kan forekomme øjeblikke, hvor Guds nåde handler uimodståeligt, så kan ethvert mennesket alligevel (i det mindste i almindelighed) modstå nåden. For det tredje hævder de, at også den sandt troende kan falde fra troen med det resultat, at mennesket for evigt vil gå fortabt. Wesley peger på, at alle kontroverserne kan føres tilbage til prædestinationslæren:

Sandelig, to sidstnævnte punkter - imodståelig nåde og den ufejlbarlige forbliven $\mathrm{i}$ troen, er den naturlige konsekvens af det første standpunkt: det ikke-konditionerede dekret (...) I sidste ende flyder de tre spørgsmål sammen til ét spørgsmål: 'Er prædestinationen absolut eller konditioneret?' Arminianerne tror, at prædestinationen er konditioneret, calvinisterne at den er absolut (Works X, 360).

Eksemplet viser, hvor kortfattet og præcist John Wesley er i stand til at stille de store kontroverser op. Det viser også, hvor han selv placerede sig. I A Dialogue betwen a Predestinarian and his Friend (ibid., 259266) gør Wesley imidlertid opmærksom på, at konditionalismen ikke er nogen moderne lære, som først Arminius fandt på. Tværtimod gør Wesleys talerør, "Vennen", opmærksom på, at prædestinationslæren ret beset er "true Turkish doctrine", altså en muhammedansk lære. Heroverfor gør prædestinationstilhængeren naturligvis gældende, at han dog har Augustin på sin side, der levede flere hundrede år før Muhammed. "Vennens" svar viser, at Wesley ikke ønsker at bryde med den augustinske arv som helhed, samtidig med at han gør gældende, at det arminianske synspunkt har de græske kirkefædre bag sig: 
Nuvel, Augustin taler nogle gange for prædestinationslæren, andre gange imod det. Men hele oldkirken i de første 400 år taler imod dig, ligesom også vestkirken gør det op til denne dag. Og den engelske kirke, både i dens katekisme, artikler og prædikener (ibid., 265).

Wesley var således $\mathrm{i}$ stand til at placere sig selv i en teologihistorie, som er større og mere omfattende, end den augustinsk-calvinske. Pointen er naturligvis, at det ikke er Wesley, der repræsenterer en ny og dubiøs lære. Det er tværtimod de hårde calvinister, der er på kant med kristendommen. Med henvisning til både Bibelen og tradition henter John og Charles Wesley modet til at gøre op med den "krigeriske blasfemi", som ligger i den dobbelte prædestinationslære. ${ }^{22}$

I sit store essay Predestination Calmly Considered fremlægger John Wesley sin mest fyldestgørende redegørelse for prædestinationslæren (ibid., 204-238). Hovedmodstanderen er fortsat den calvinske lære. Men også den bløde lutherske position i Konkordieformlen afvises som halvhjertet (dog uden at nævnes ved navn). Wesley vender sig nemlig her mod den såkaldt 'enkelte' prædestinationslære, som siger, at Gud ganske vist har udvalgt nogle til frelse, men at Gud dermed ikke har prædestineret nogen til fortabelse. Wesley finder denne løsning inkonsistent, fordi selve det ikke-at-være-udvalgt er det samme som at være forkastet; og hvis nogen siger, at Gud ganske vist har udvalgt alle til frelse, men ikke samtidig skænker alle Helligåndens gave, som giver kraften til at tro, så er man lige vidt (ibid., 206-208). "den ubetingede udvælgelse kan ikke optræde uden forkastelsens kløvede fod" (ibid., 208).

Man kunne her mene, at apokastasis-lærens påstand om, at alle ubetinget - er forudbestemt til frelse, ville udgøre det naturlige alternativ til augustinismens mørke. Men det er karakteristisk, at Wesley end ikke overvejer apokastasis-læren; sandsynligvis opfatter han læren om alles frelse som ubibelsk. Alternativet til Calvin og den halvhjertede lutherske position er ifølge Wesley alene den konditionelle frelsesuniversalisme, som også tager menneskets respons i syne.

\section{Wesleys laere om den imødekommende nåde}

Hvor central en rolle friheden indtager i Wesleys forståelse af nåden fremgår allerede af, at han i sin allerførste universitetsprædiken understreger, at Adam i Edens Have blev prøvet ved at skulle vælge mellem Guds Ord og slangens tale. ${ }^{23}$ Anderledes bliver det ikke efter syndefaldet. For nåden ønsker ikke at tvinge viljen, men at sætte den fri, så mennesket selv kan sige ja til Guds Ja.

Nu kunne man så mene, at hvis Wesley på denne måde skaber plads til menneskets frie gensvar til nådens tilbud, vil han i praksis 
forudsætte et pelagiansk frihedsbegreb, ifølge hvilket mennesket selv kan bestemme, om det vil følge Gud eller ej. Denne anklage mødte Wesley da også allerede i samtiden. Men faktisk fremfører Wesley en arvesyndslære helt $i$ tråd med Augustin og reformatorerne. Uden nåden var mennesket et vredens barn, fuldstændig uden håb. ${ }^{24}$ Wesley var arminianer, men ikke pelagianer. Af samme grund nærede Wesley ikke nogen forhåbninger om, at bestemte viljeskræfter er intakte efter faldet. Derimod var det Wesleys overbevisning, at menneskets vilje aldrig er alene. Intet menneske lever nogensinde uden nåden, der til stadighed omgiver mennesket og uafladeligt arbejder på dets befrielse fra syndens åg. Som det prægnant formuleres: "Intet menneske synder, fordi han ikke har nåden, men fordi han ikke gør brug af den nåde, som han har" (Works VI, 512). "Den naturlige frie vilje i menneskehedens nuværende forfatning forstår jeg ikke noget ved. Jeg hævder alene, at der findes en grad af fri vilje, som bliver overnaturligt genskabt for ethvert menneske sammen med det overnaturlige lys, som 'oplyser ethvert menneske, der kommer ind i verden"' (Works X, 22930).

Læren om prevenient (nogle gange også kaldet preventing) grace er således afgørende for at forstå Wesleys løsning på det klassiske problem om forholdet mellem nåden og den frie vilje. Hvis man kan tale om, at Wesley er optimist på menneskets vegne, er denne optimisme teologisk begrundet. Selve tanken om det naturlige menneske og dets eventuelle kræfter eller mangel på samme er ifølge Wesley en abstraktion fra det virkelige menneske, som aldrig lever uden Gud. Som han formulerer det i sermonen On Working Out Our Own Salvation (1785): "Der findes ikke et menneske, som lever i en tilstand af ren natur; der findes ikke noget sådant menneske, medmindre han har kvalt Ånden, dvs. er helt tom for Guds nåde." ${ }^{25}$ Men mennesket har netop ikke kraft til at kvæle Guds frie nåde. For til nådens primat hører, at Gud fortsætter med at komme mennesket i møde ved sit overtalende ord.

Nærmere bestemt skelner Wesley mellem "prevenient/preventing grace, justifying grace", og "sanctifying grace". ${ }^{26}$ Han hævder, at 'den frie vilje' ikke er en naturlig tilstand, fordi menneskets samvittighed altid er influeret af den forudgående nåde. Frelsen $i$ egentlig forstand begynder imidlertid først ved den nåde, som viser sig i retfærdiggørelsen og helliggørelsen. Særligt efter sin lutherske omvendelse i 1738 træder retfærdiggørelsens rene nåde frem hos Wesley, således at han til stadighed fremhæver to aspekter ved nådens gerning, for det første den ufortjente nåde, som genopretter mennesket ved Guds tilgivende kærlighed, for det andet Helligåndens kraft, som virker i os 
"både at ville og at virke" (Fil 2,12 f.) I førnævnte sermon giver Wesley en sammenhængende redegørelse herfor. Her hedder det, at menneskets frelse ved nåden har to aspekter, retfærdiggørelse og helliggørelse:

Gennem retfærdiggørelsen bliver vi frelst fra syndens skyld og har fået Guds velvilje (favour) igen; gennem helliggørelsen bliver vi frelst fra syndens kraft og rod og har fået gudbilledligheden tilbage. Al erfaring viser, ligesom også Skriften gør det, at denne frelse er både øjeblikkelig og gradvis. Den begynder det øjeblik, vi bliver retfærdiggjorte, i den hellige, ydmyge, venlige og tålmodige kærlighed mellem Gud og menneske. Den vokser gradvist fra dette tidspunkt, som 'et sennepskorns kerne, som til at begynde med er den mindste af alle kerner', men efterhånden frembringer store grene og bliver til et stort træ; indtil hjertet på et senere tidspunkt bliver renset fra synd og fyldes af ren kærlighed til Gud og menneske (Works VI, 509).

Så længe det drejer sig om retfærdiggørelsens ufortjente nåde, bevæger Wesley sig både $\mathrm{i}$ sprog og sag $\mathrm{i}$ samme univers som Luther. Men fordi nåden ikke som hos Luther er uimodståelig, lægger Wesley vægt på helliggørelsens nåde, som bliver til gennem menneskets samarbejde med Gud. Det er i denne sammenhæng, at Wesley kan tale om, at kristenmennesket godt kan være syndfrit, ja endda som regel vil være det. Denne lære om den kristnes perfektion ligger naturligvis milevidt fra Luthers påstand om, at synden bliver ved med at røre på sig hos den kristne. Wesleys kristelige perfektionisme ligger ligeledes, som vi nu vil se, langt fra Grundtvigs menneskesyn.

\section{Frelsens vilkår $i$ Grundtvigs kirkelige anskuelse}

Jeg har ikke været $\mathrm{i}$ stand til at finde nogen eksplicit teologisk refleksion over den forberedende nåde hos Grundtvig, selv om selve tankegangen utvivlsomt ville kunne opspores i Grundtvigs bibelhistoriske læsninger, der ofte kredser om Guds forsyn. Men også Grundtvig står som sagt fast på, at Gud giver plads for menneskets ja eller menneskets nej. I Den christelige Børnelcerdom opfatter Grundtvig dåbspagten som en aftale med to parter, og han beder sin læser at lægge nøje mærke til, at troens ord ved dåben (dvs. trosbekendelsen) er

den ene Deel af vor Daabs-Pagt, det vil sige: den Aftale, vi paa Vorherres Vegne skal giøre med alle dem, der ved Herrens Daab, i Faderens og Sønnens og Helligaandens Navn, vil optages i Vorherres Jesu Christi Menighed, og derved faae Deel i den Synds-Forladelse og det Salighedens visse Haab, som han har lovet at skiænke alle dem, der "troer"og er "døbte" (VU VI, 40). 
Den ene side af dåbens aftale er altså "det lille Ord af Herrens egen Mund", som præsten eller menigheden fremsiger "paa Vegne af Gud". Hvad er så den anden del af aftalen? Af den umiddelbart efterfølgende sætning fremgår, at menneskets del af aftalen er det "ja", som udtales af den, der skal døbes (ved gudmoderen eller gudfaderen). Og netop på dette afgørende sted i Grundtvigs kirkelige anskuelse træder konditionalismen frem, for troens ja skal være ærligt ment og den døbende skal livet igennem fastholde sin del af dåbens pagt, aftale eller kontrakt:

saa det følger af sig selv, at hvem der enten kun paa Skrømt svarer $J a$ ved denne Pagt eller Aftale, eller gaaer dog siden fra sit Ord, har slet ingen Gavn af sin Daab, slet ingen Lod eller Deel i hvad Herren kun har lovet dem, som i Sandhed troer hans Ord og bliver troe indtil Døden ( VU VI, 40). ${ }^{27}$

Viljen til at tro på Gud som skaber og frelser er altså det uomgængelige vilkår for dåbens gyldighed. Dåben virker ikke magisk, blot ved at blive udført. Guds løfte indfries kun under forudsætning af, at mennesket holder sin del af aftalen. ${ }^{28}$ Betyder dette så, at Grundtvig skulle mene, at mennesket "selv", uden Helligåndens hjælp, kan beslutte sig til at tro? Er troen ikke under hånden blevet menneskets egen gerning? Nej, for Grundtvig taler højt og tydeligt om "tro" på to forskellige niveauer.

Den ene tro er den "naturlige tro", som er mulig for ethvert sandhedssøgende menneske i kraft af at være skabt i Guds billede og lighed. Det er for hele Grundtvigs argumentation en helt afgørende pointe, at Kristus ved dåbspagtens indgåelse "ikke kunde eller ville forlange mere af et Menneske ved Daaben end det var det gamle [altså endnu ikke omvendte!] Menneske muligt at fatte, fæste Lid og sige Ja til" (ibid., 20). Der er således ifølge Grundtvig opstillet det "Vilkaar" (ibid., $21 \mathrm{f}$.) for dåben, at det naturlige menneske skal forsage Djævelen og alle hans gerninger, også mens mennesket endnu selv er synder og ikke har modtaget kraften til at overvinde synden i sig selv:

Hvad vi nemlig med Forsagelsen ved Daaben kan og skal svare ja til, det maa jo ikke være mere end hvad vi, førend Gienfødelsen og Fornyelsen, som har sin Kilde i Daaben, kan med Guds Hjelp arlig og oprigtig svare ja til (ibid., 22).

Som regel argumenterer Grundtvig i denne sammenhæng rent skabelsesteologisk, det vil sige med henvisning til menneskets iboende gudbilledlighed, der bliver ved at røre på sig i form af en sandhedssøgen og en søgen efter dåbens genfødelse ( $\mathrm{fx}$ ibid., $20 \mathrm{og}$ 48). Men Grundtvig kan også henvise til "Guds Hielp". Skabelsens menneske er 
nemlig aldrig alene, men til stadighed omgivet af Guds forsyn. Hos Grundtvig findes ingen abstrakt skabelsesteologi, for selv om Gud sætter det skabte menneske fri, forlader Gud aldrig sin skabning. I denne forstand kan man sige, at skabelsestroens forsynslære hos Grundtvig varetager den funktion, som hos Wesley indtages af tanken om prevenient grace. I Grundtvigs tilfælde drejer det sig dog ikke om den realiserede frelse, men om at skabe forudsætningerne for frelsens realisering i dåben.

Det er imidlertid et nærliggende spørgsmål, om ikke denne interesse for frelsens proces fører mennesket tilbage på selv, i stedet for at henvise mennesket til at søge tilflugt i Guds handlen. Forbliver ikke enhver tale om dåben som en "Pagt" eller en "Aftale", eller om nådens "Vilkaar" og "Forpligtelser" ikke i lovens rum, der kaster mennesket tilbage på sig selv? Grundtvig er lutheraner nok til at stille spørgsmålet selv, og hans svar er gennemtænkt:

Man tager for en Lov, hvad der et Evangelium, ikke et Paabud om hvad vi skal giøre og lade for at blive salige, men et Tilbud om at giøre os salige, naar vi ærlig vil gaae ind paa Herrens Vilkaar. Forsager du og troer du, siger Herren, saa døber jeg dig med den Helligaand, (ibid., $18 \mathrm{f}$.)

Dåbens ord er altså at forstå som Guds invitation til det skabte, men faldne menneske om at træde ud af synden og ind i nådens rige. Som sådan er evangeliets løfte et tilbud, der ikke voldeligt fratager mennesket dets gudgivne mulighed for at sige ja (eller nej), men taler til det skabte menneske i dets evne og kraft til, for det første, at frasige sig løgnens verden og, for det andet, at ville forbinde sig med sandheden, skønheden og godheden i tro, håb og kærlighed. Det er således alene Guds Ord, der virkeliggør frelsen; men frelsen er betinget af det naturlige menneskes frie ja til Gud.

Grundtvigs fremhævelse af menneskets medskabte gudbilledlighed indtager således den plads, som den forudgående nåde har hos Wesley. Forskellen er, at hos Grundtvig taler Gud til det gamle menneske, mens den forudgående nåde hos Wesley er virksom på en overnaturlig måde i forhold til det naturlige menneske. Men selv om Grundtvig og Wesley placerer mødet mellem Gud og menneske på et forskelligt sted (den ene i skabelsesteologien og den anden i helliggørelseslæren), så kommer de frem til den samme pointe, nemlig at Guds frelse inddrager det menneske, der skal arbejde med på sin egen frelse.

Indtil nu har vi alene set på dåbens form som en gud-menneskelig kontrakt før dåbens genfødelse. Men der består ifølge Grundtvig også et gensidigt forhold mellem nåden og det genfødte menneske. For "hos alle dem, faa eller mange, som sanddru siger Ja til Daabs-Pagten og søger Gienfødelsen i Daaben, hos dem alle begynder han [Kristus] sin 
gode Gierning" (ibid., 48). Denne gode gerning fører fra syndsforladelsen og genfødelsen i dåben hen til nadverens kærlighedsmåltid. Der går ifølge Grundtvig en bestemt vej fra Badet til Bordet, fra dåben til nadveren. Der er på dette sted, at han taler om troens vækst. Grundtvig anerkender nemlig fuldt ud, at der godt kan være noget, som det naturlige menneske, der siger ja til dåben, endnu slet ikke kan forstå, "men som dog alle Troende og Døbte, benaadede og gienfødte, Mennesker vil komme til at troe, som Tilfældet klarlig er med Herrens Ord til os ved hans Bord med den hellige Nadver" (ibid., 31). Der er hos Grundtvig en bevægelse fra dåbens tro til kærligheden til Gud og næsten i nadverens måltid, en bevægelse, som ikke kan andet end at tage tid. Ligesom hos Wesley er der hos Grundtvig tale om en bevægelse fra retfærdiggørelse til helliggørelse, fra begyndende tro til mere tro, fra et svagt håb til et stærkt håb, og fra en meget begrænset kærlighed til en omfattende kærlighed. Men forskellen fra Wesley er, at denne "saliggørelsens orden" hos Grundtvig er bundet til det ydre, nærmere bestemt til nadveren som kærlighedens sakramente:

(det er) først ved Herrens Bord, ved de Ord af hans Mund, som giør os deelagtige i hans for os hengivne Legeme og hans for os til SyndsForladelse udgydte Blod, derved, at Herrens Aand i vort kiærlige Fællesskab (på Græsk: koinonia og paa Latin: communio) med Herren og med hinanden lader os føle den salige Vished, at alle vore Synder blev udslettede (...), og at vi, i hans Kiærlighed, er overgangne fra Døden til Livet" (ibid., 48).

Kristendommens vej indad - i troens, håbets og kærlighedens fordybelse - går altid gennem det ydre liv. At være kristen er ikke noget som helst andet end at være menneske; men at være menneske er ikke blot at være et individ. At være et helt og fuldt menneske er at leve sammen med andre ud af troens, håbets og kærlighedens overskud. ${ }^{29}$

Selve tanken om nåden som et guddommeligt tilbud, der er attraktivt nok til at fore mennesket ind $\mathrm{i}$ troen, finder vi også formuleret $\mathrm{i}$ Grundtvigs prædikener. I sin Prcediken til 1ste Søndag efter Trinitatis 1855 taler Grundtvig ligefrem om, at evangeliet lokker mennesket ind i frelsen. At finde hvile hos Gud,

dertil hjælper Loven os slet ikke, det er Naaden for Naade, som skrevet staaer: Loven er givet med Moses men Naaden og Sandheden er født med Jesus Christus, og Naadens Ord med Naadens Aand er ingen Lov, men et Evangelium, er intet Paabud, der truer alle Overtrædere med Forbandelse, men er et naadigt Tilbud, der lokker os med den evige Velsignelse til at troe paa det eneste Navn under Solen, som det er Mennesket givet at frelses og saliggiøres i, ${ }^{30}$ 
Bestemmelsen af evangeliet som en indbydelse, der lægger op til troens frie gensvar, er således en genkommende tanke hos Grundtvig.

\section{Grundtvigs store vision om den anden chance}

Vi kommer nu til det sted, hvor Grundtvig føjer noget afgørende nyt til klassisk evangelisk teologi, hvad enten den repræsenteres af Luther eller Wesley. Selve tanken om den anden chance findes allerede forholdsvis tidligt i Grundtvigs forfatterskab, idet tredje bind af Christelige Prodikener eller Søndags-Bog fra 1830 bringer en udførlig prædiken eller afhandling herom. ${ }^{31}$ Den kirkelige anskuelse indebærer jo at forklare skriften efter troens regel, hvorfor trosbekendelsens fremhævelse af Kristi nedfart til dødsriget ifølge Grundtvig har særlig betydning. Derfor må også 1 Pet 3 læses ud fra den forudsætning, at Kristus ikke tog ned til helvede for at straffe, ja end ikke for at dømme de afdøde. Kristus kom derimod til Dødsriget som frelser: "han som er Naaden og Sandheden selv, og paa hvis Læber Naaden var udøst, [ ] han kom aldrig nogensteds, uden at Naade-Solen skinnede som den Eenbaarnes Herlighed". ${ }^{32}$ Kristus kom nemlig til de døde for at prædike det selvsamme evangelium, som han allerede havde bragt til jøderne og disciplene: Omvend jer og tro evangeliet! Dermed er de afdøde, som aldrig har mødt evangeliets budskab, fordi de levede før kirken eller uden for kirkens rækkevidde, stillet i helt den samme situation som enhver kristen, der bliver tilspurgt, om han eller hun vil døbes.

Samtidig er Grundtvig overbevist om, at der ikke findes frelse i noget andet navn end i Jesus Kristus. Men så er spørgsmålet jo, om frelsen kun er for de kristne. "Uden for kirken ingen frelse", som et gammelt ordsprog har sagt. Men sagde ikke også Jesus til røveren på korset, der omvendte sig, at "I Dag skal du være med mig i Paradis"?, spørger Grundtvig. Og hans ræsonnement er atter en gang både evangelisk og præget af almindelig retfærdighedssans:

Det er da klart, at enten maae vi selv fornægte vor Christendoms Sandhed til Salighed, eller vi maae ansee dem alle for at være evig fortabte, der ikke her paa Jorden hørde og troede, eller vi maae antage, at Evangeliet ogsaa prædikes for de Afdøde, saa at alle de der ere af Sandhed, komme til at høre Herrens Røst, at troe paa ham, og blive salige. Men det Første forbyder hos en Troende sig selv, det Andet forbyder os vor egen Billighed og Menneske-Kiærlighed, endsige da den himmelske Faders, og vi maatte da vælge det Tredie, om der saa end hverken i vor Troes-Bekiendelsè eller i Skriften var mindste Vink derom. $^{33}$

Men der er altså netop et vink både i trosbekendelsen og i Skriften. Nedfarten til dødsriget er derfor et motiv, som Grundtvig ofte udnytter 
og sætter i forbindelse med Jesu ord til røveren på korset. ${ }^{34}$ Temaet er $\mathrm{da}$ også behandlet $\mathrm{i}$ mange prædikener fra Grundtvigs hånd, ikke mindst i forbindelse med Første Søndag efter Trinitatis, hvor evangelieteksten er fortællingen om den rige mand og Lazarus i Luk 16, mens epistelteksten er fra 1 Pet $3 .^{35}$

Grundtvigs prædikentolkninger til Første Søndag efter Trinitatis er varierede, men konsistente. Intetsteds bygger Grundtvig bro hen over svælget mellem den rige mands pinested og Lazarus' hvilested i de dødes rige. Apokatastasis-læren ligger uden for hans horisont, både af bibelteologiske grunde og på grund af modsigelsens grundsætning:

Vist nok kan og vil hverken Faderen eller Sønnen udstrække sin Kjærlighed saaledes til Helvede, som Verden forlanger, da Sandheden umulig kan elske Løgnen, eller den sande Kjærlighed enten i Tid eller Evighed forlige sig med Falskhed og Misundelse, saa at dersom der ikke havde været andet i Helvede end Djævelen og hans Børn, da vilde det $\mathrm{i}$ alt Fald have været forgjæves, at Frelseren der prædikede for Aanderne, som før ikke trode. ${ }^{36}$

I flere prædikener fremhæves endvidere, at man ikke kan vente med at beslutte sig, til man eventuelt måtte få en anden chance efter døden. For ifølge lignelsen er det netop omsonst, at den rige mand beder om at få sendt den fattige Lazarus til at advare den rige mands brødre. Pointen er tværtimod, at der er svælg mellem pinen og hvilen. Der er derimod ikke noget svælg mellem denne verden og hin verden. For hvad enten vi lever på jorden eller befinder os i dødsriget, drejer teksten sig ikke om rigdommens straf og fattigdommens belønning, men om at "det er Hjærterne, der pines eller trøstes efter den Maade, hvorpaa de har betragtet og benyttet deres Kaar i denne Verden". 37 Grundtvig forudsætter endnu engang en frihed $\mathrm{i}$ åndelige sager. Men friheden er vel at mærke ikke afhængig af den intellektuelle klarhed, hvormed vi forstår eller ikke forstår troen. Det glædelige ligger derimod i, at "ingen er gaaet fortabt, som hørte og fulgte det Guds Ord, der lød for hans Øren, enten det var dunkelt eller klart". ${ }^{38}$ Opgaven, der bliver stående for enhver kristen, er derfor at lade gudskærligheden vokse og frygten for Gud og det hinsidige aftage (jf. 1 Joh 4,18).

Grundtvig er imidlertid til stadighed klar over, at vi af gode grunde kun kan gøre os utydelige forestillinger om Kristi nedfart til dødsriget. Selv om Grundtvig i sine salmer som regel fremstiller Lysets ankomst til Dødens og Mørkets Rige som en korporlig overvindelse af Djævelen, så viser hans prædikener, at han meget vel véd, at både Helvede og Himmerig er åndelige realiteter og ikke legemlige lokaliteter: 
Endelig skal vi ogsaa lære at se Lys i Herrens Lys, saa at hvor Talen, som her, er om Sjæle uden Legeme, der maa ved Sted egentlig kun tænkes paa Tilstand og ved Fangenskab paa aandelig Trældom og Hjærteklemme, saa der er ingen væsentlig Forskjel mellem hvad vi kalder Helvede her og Helvede hisset; og han, som baade selv forkyndte og lader sin Aand forkynde Evangelium midt i Helvede paa denne Side Graven, vilde hin Sides sikkert gaa hen og giøre ligesaa, for at de, som vilde blive ædru af Djævelens Snare, vilde omvende sig og tro Evangelium, ogsaa da kunde reddes som en Brand af Ilden. ${ }^{39}$

To teologiske pointer insisterer Grundtvig til stadighed på. For det første, at Kristus ikke bare kommer til de lykkelige i "Hvilestedet", men også til de ulykkelige i "Pinestedet". For det andet, at Kristus kommer til dødsrigets porte som frelser, og ikke som fordømmer:

Saasandt derfor, som Vorherre Jesus Christus nedfoer til de Dødes Rige med Hvilestedet og Pinestedet, som han selv peger derpaa i Dagens Evangelium, saavist nedfoer han ogsaa som Frelser, og saafremt han prædikede for dem i Fængselet, som fordum ikke troede, da prædikede han i samme Aand, som han prædikede paa Jorden: Guds Rige er nær, omvender eder og troer Evangelium! $!^{40}$

I salmerne kan Kristi nedfart til Dødsriget til tider få Grundtvig til at lovsynge Guds-Ordets triumf over Djævelen og dødens trone, sådan som vi eksempelvis ser det i salmen Til Helvede vor Drot nedfoer ( $G S V \mathrm{~V}, 97)$. Men mere karakteristisk for Grundtvig er, at han fastholder tosidetheden i forholdet mellem Gud og menneske. Det er dette motiv, der kommer frem i den store salme I Kveld blev der banket på Helvedes Port fra 1837 (GSV I, $243=$ =DS 213, 2003udgaven). Også her fremstilles Kristus som den, der nedkæmper øgler og drager (strofe 1-3). Men resultatet er, at fangerne i dødsrigets mørke atter får modet og kraften til selv at rejse sig op. Først på albuerne (strofe 4-5), men snart efter bevirker Kristus-lysets nærvær, at fangerne tør rejse sig helt op - dog kun for atter at knæle ned og velsigne den kommende:

I Helvede skinned Guds Herligheds Glands,

Guldfarved de Djævle kulsorte,

Men Murene revned for Straaler i Dands,

Af Hængsel fløi Helvedes Porte!

Sig reiste de Fanger nu alle paa Stand,

Men dog for kun dybt at nedknæle

Velkommen, velsignet, vor Frelser-Mand!

Det lød fra utallige Sjæle!

$\mathrm{Nu}$ “Adam, hvor er du?", blev hørt med en Røst,

Som Lærkens en Pindsedags-Morgen,

Da fødtes i Helved den evige Trøst, 
Sin Hel-Sot fik Menneske-Sorgen!

(GSV I, 243, 8-10 = DDS 2003, 213).

Den store pointe er her naturligvis, at de, der frelses, frelses alene gennem Kristi komme. Men den anden og underordnede, men dog samtidig nødvendige pointe er, at fangerne nu selv kan rejse sig $\mathrm{i}$ mødet med Kristus-lyset. Nu først vækkes Adam af sin åndelige dvale. Når Adam og Eva spiller så stor en rolle i salmen (strofe 10-16), skyldes det, at de er billedet på det gudbilledlige menneske, der aldrig kom til at finde Gud i den række af begivenheder, som udgør skabelsen. Men nu, på klarhedens dag, finder Adam og Eva den Gud, i hvis billede de var skabt og hvis lighed de havde efterstræbt.

Ved nådens ankomst sættes mennesket fri. Denne frihed var mennesket skabt til fra skabelsens morgen, men først ved Kristi komme kan mennesket realisere sin gudgivne frihed. Så langt er Wesley og Grundtvig enige. Dermed hævder de også begge, at friheden hører hjemme også i menneskets forhold til Gud. For Gud inviterer utrætteligt til troens ja, der forstås som gensvaret på evangeliets "Tilbud". Men Gud respekterer også menneskets nej, for også magten til at sige nej er et privilegium, der er skænket mennesket af Gud.

Uanset hvordan en nutidig metodisme og en nutidig grundtvigianisme vil forholde sig til den lære om den dobbelte udgang, som Wesley og Grundtvig hver især repræsenterer, har opgaven i denne artikel alene været at gøre opmærksom på den indre logik, som kommer til udtryk i frelseskonditionalismen: i begge tilfælde er nåden universel, for så vidt som den rækkes til alle, men nåden realiseres ikke hen over hovedet på mennesket. Nådens logik er præget af en samtidighed af nådens guddommelige førstehed og af menneskets plads som den frie andethed, der selv skal ville sin frelse. Forholdet mellem Guds frie nåde og menneskets frie gensvar er asymmetrisk, men tosidet.

\section{Litteraturliste}

Bekenntnisschriften (1930), Die Bekenntnisschriften der Evangelischlutherischen Kirche: hrsg. im Gedenkjahr der Augsburgischen Konfession, Göttingen: Vandenhoeck og Ruprecht.

Brandt, C. J. (1875), Prcedikener af N. F. S. Grundtvig $i$ Frederikskirken 1832-39, Kjøbenhavn: Karl Schönbergs Forlag. Brosché, Fredrik (1978), Luther on Predestination: The Aninomy and the Unity between Love and Wrath in Luther's Concept of God, Uppsala: Almquist \& Wiksell International. 
Christensen, Torben et al. (red.) (1962-83), Luthers skrifter i udvalg, bind 1-5, København: G.E.C. Gad.

Colle, Ralph del (2002), "John Wesley's Doctrine of Grace in Light of the Christian Tradition", International Journal of Systematic Theology 4:2, 172-189.

Grane, L. (2000), Confessio Augustana, Frederiksberg: Anis.

Grell, Helge (1992), England og Grundtvig: Grundtvigs møde med England og dets betydning for hans forfatterskab, Århus.

Gregersen, Niels Henrik (2002), "Når der bliver mere ud af mindre: Grundtvigs menneskesyn" i Henrik Wigh-Poulsen et al. (red.), Grundtvig og Kierkegaard. En Samtale på høje tid, København, 11-30.

Gregersen, Niels Henrik (under udgivelse), "Den imødekommende nåde: John Wesleys opgør med den reformatoriske tradition" i Else Marie Wiberg Pedersen og Bo Holm (red.), Nåden og den frie vilje, Frederiksberg.

GSV I-VI = Balslev, Th. et al. (1944-64), Grundtvigs Sang-Vark. Samlet Udgave, bind 1-6, København.

Kierkegaard, P. C. (1848), Foredrag ved Roskilde Præstekonvent d. 20. oktober 1847, Dansk Kirketidende, nr. 122-123, København.

Kjærgaard, Jørgen (2003), Salmehåndbog, I-II, Esbjerg: Det Kgl. Vajsenhus' Forlag.

Kolb, Robert \& Wengert, Timothy J. (red.) (2000), The Book of Concord: The Confessions of the Evangelical Lutheran Church, Minneapolis: Fortress Press.

Larsen, Bent Dalsgaard (2002), Augustin: Om Guds stad, Århus: Aarhus Universitetsforlag.

Lindhardt, P. G. (1974), Konfrontation: Grundtvigs prodikener $i$ kirkeåret 1854-55 på baggrund af Kierkegaards angreb på den danske kirke og den "officielle" kristendom, København: Akademisk Forlag.

Lindhardt, P. G. (1977), Regeneration: Grundtvigs Proedikener $i$ kirkeåret 1855-56, København: Akademisk Forlag.

Madsen A. Ellen (1983), Luthers skrifter $i$ udvalg bind 5: Om den tralbundne vilje, Århus: Aros.

Outler, Albert C. (1977), "John Wesley: Folk-Theologian”, Theology Today 34:2, 150-160.

Outler, Albert C. \& Heitzenrater, Richard P. (red.) (1991), John Wesley's Sermons: An Anthology, Nashville: Abingdon Press.

Rakestraw, Robert W. (1984), "John Wesley as Theologian of Grace", Journal of the Evangelical Theological Society 27:2, 193-203.

Sidste Proedikener $=$ Brandt, J. C. (red.) (1880), N. F. S. Grundtvigs Sidste prodikener $i$ Vartov kirke 1861-72, København. 
Schjørring, J. H. (1990), Grundtvigs billedsprog og den kirkelige anskuelse, Frederiksberg: Anis.

Søndags-Bog = Grundtvig, N. F. S. (1827-30), Christelige Proedikener eller Søndags-Bog, bind 1-3, København.

Thaning, Kaj (1963), Menneske først -: Grundtvigs opgør med sig selv, bind 1-3, København.

Thodberg, Christian (1989), "En glemt dimension i Grundtvigs salmer - bundetheden til dåbsritualet”(1969), genoptrykt i Syn og sang: Poesi og teologi hos Grundtvig, København, 7-119.

Thrap, Daniel (ovs.) (1884), Aurelius Augustinus: Enchiridion: en kort Haandbog om Tro, Haab og Kioerlighed, Christiania.

Thulstrup, Johannes (1977), Anselm af Canterbury: Hvorfor Gud blev menneske, København: C. A. Reitzels Boghandel.

Thyssen, Anders Pontoppidan (1993), "Grundtvigianismen og J. C. Christensens folkekirke I-II", Dansk Kirketidende 145:23-24, 340343 og 362-367.

Tyson, John R. (ed.) (1989), Charles Wesley: A Reader, New York: Oxford University Press.

US I-X = Begtrup, Holger (1904-09), Nik. Fred. Sev. Grundtvigs udvalgte Skrifter, København.

$V U \mathrm{I}-\mathrm{X}=$ Christensen, G. et al. (1940-49), N. F. S. Grundtvigs Varker $i$ Udvalg, bind 1-10, København.

$W A=$ Luther, Martin, Weimarer Ausgabe.

Wainwright, Geoffrey (1993) "Reason and Religion: A Wesleyan Analogue to Grundtvig on Modernity and the Christian Tradition" i A. M. Allchin, D. Jasper, J. H. Schjørring, and K. Stevenson (red.), Heritage and Prophecy: Grundtvig and the EnglishSpeaking World, Aarhus, 191-214.

Works = Jackson, Thomas (ed.) (1978), The Works of John Wesley: Complete and Unabridged, 3rd edition [1872], reprint Grand Rapids: Baker House, vols I-XIV.

Noter

$1 \quad$ N. F. S Grundtvig, "Verdens Krønike 1812" (US II, 262-63). Se også Grell 1992, særligt 17-20.

2 Thaning 1963, bd. III, 585, der ud fra en skabelsesteologisk Grundtvigtolkning fremhæver forskellen mellem Charles Wesleys længsel mod det himmelske fædreland og Grundtvigs understregning af sammenhængen mellem helgen her og helgen hisset: “'Grundtvigs Helgen' (H. Simonsen) er ikke en pilgrim, der søger mod frelsen i himlen. Helgenen lovsynger derimod den kærlighed, som er den samme 'her og hist', og som, når 
tiden er inde, også låner mennesket vinge til at flyve ud over graven". Hertil må dog siges, at helt det samme motiv også udtrykkes af John Wesley, fx i sermonen "The Scripture Way of Salvation" fra 1765: "(Salvation) is not a blessing which lies on the other side [of] death... It is not something at a distance: it is a present thing, a blessing which, through the free mercy of God, ye are now in possession of' (Works VI, 44). En nem og tilgængelig udgave er John Wesley's Sermons: An Anthology (Outler et al. 1991).

US II, 308-309.

Wainwright 1993, 191-214.

Prædiken til 1. S. e. Trin. 1836 (Brandt 1875, 347).

Se nærmere Colle (2002, 172-189), der med rette peger på, at Wesleys interesse for frelsens stadier adskiller ham fra Luther: "As compared to Luther and even Calvin, Wesley is rather explicit in distinguishing differing stages in the salvific process. Whereas the former, especially Luther, focus on the efficacy of grace in one primary locus such as justification or predestination, Wesley is more apt to describe the distributive effects of the one grace of Christ along the processive stages of Christian salvation", 176.

7 Se fx John Wesley, "Christian Perfection" (Works VI, 1-22), og sammenlign med Grundtvigs kommentar i Verdens-Krøniken 1817, 355: "Det var Vesleys Feil at ville fabrikere Christne..., men det [engelske, NHG] Folk, der sætter sin Salighed i Fabriker uden Christendom, har vist ikke Ret til at laste ham".

8 Grundtvigs stadigt skiftende kirkesyn i almindelighed og syn på den danske kirkeordning i særdeleshed er med stort overblik analyseret af Anders Pontoppidan Thyssen (1993).

Se Outler 1977, 150-160.

10 N. F. S. Grundtvig, "Den christelige Børnelærdom" [1868] (VU VI, 108).

11 Jf. atter Den Augsburgske Bekendelse fra 1530: "Om dåben lærer de, at den er nødvendig til frelse, og at Guds nåde tilbydes ved dåben..." (Artikel 9, efter Leif Granes oversættelse).

12 Se hertil nærmere i min artikel, "Den imødekommende nåde: John Wesleys opgør med den reformatoriske tradition" (Gregersen under udgivelse).

13 Man kan overveje, som foreslået af prof. Theodor Jørgensen i en personlig samtale marts 2004, om der ikke kunne ligge en betydningsforskel mellem at tale om frelsens vilkår og om dens betingelser. Distinktionen er hårfin, men kunne formuleres som følger: Frelsens "vilkår" er de vilkår, som nu engang de facto er knyttet til dåbsbekendelsen som menneskets ja og amen til Guds forudgående nådestilsagn; frelsens "betingelser" (og dermed udtrykket "frelseskonditionalisme") kunne derimod forstås som en a priori betingethed i selve det guddommelige nådestilsagn. Denne forskel ville ganske rigtigt være betydelig, fordi nådens tilsagn i sidstnævnte tilfælde kun ville gælde med forbehold fra Guds side. Imidlertid er heller ikke Wesley konditionalist i sidstnævnte forstand, fordi Guds nådestilsagn i sig selv er uforbeholdent, 
men altså inviterer til tro (og for så vidt fordrer troens gensvar for at være virksom). Der må således skelnes mellem de "betingelser", som er givet med frelsens vej gennem mennesket, og en evt. betingethed $\mathrm{i}$ det guddommelige løfte.

14 En kortfattet beskrivelse af den sene Augustins synds- og frelseslære findes i Håndbog om tro, håb og karlighed, særligt kap 8-10 og 24, mere udførligt i Om Guds Stad, bog 13-15 og 20-21. Vedrørende den besynderlige teori om forbindelsen mellem englenes fald og menneskers frelse, se Håndbog 9.29 og Om Guds Stad bog 11.33. Tanken er videreført af Anselm af Canterbury, Hvorfor Gud blev menneske?, 1.16.

15 Oversættelser efter Ellen A. Madsen (1983, 45 og 244).

16 Jf. Brosché 1978, 143: "it is not predestination which is a consequence of justification, but justification which is an effect of predetermination". Her citeret efter Luthers skrifter i udvalg, bind 1, red. Niels Nøjgaard, 96111, her s. 106-107, (se Christensen 1962-86).

18 Formula Concordiae. Solida declaratio, XI, 68 og 86. Tekst i Die Bekenntnisschriften der evangelisch-lutherischen Kirche, herausgegeben im Gedenkjahr der Augsburgischen Konfession, Göttingen: Vandenhoeck \& Ruprecht [1930] $1967^{6}, 1083$ og 1088. Der findes udmærkede oversættelser til engelsk, senest Kolb \& Wengert 2000.

19 Fra Hymns on God's Everlasting Love, To which is Added the 'Cry of a Reprobate' and 'The Horrible Decree', 1741 (First Series, XIV). Her citeret efter Tyson 1989, 302-303. Se Kjærgaard 2003, II, 458 f.

21 Se "The Question 'What is an Arminian' - Answered by a Lover of Free Grace", Works X, 358-361.

22 Jf. Charles Wesleys salme, "The Horrible Decree" fra Hymns of God's Everlasting Love (First Series XVII): "O HORRIBLE DECREE / Worthy of whence it came! / Forgive their hellish blasphemy / Who charged it on the Lamb, / whose pity Him inclined, / To leave His throne behind, / The Friend and Saviour of mankind, / The God of grace and love".

John Wesley, "The Image of God" (1730), citeret fra John Wesley's Sermons: An Anthology: "menneskets frihed forlangte, at Adam skulle underlægges en slags prøve (trial); ellers ville han ikke have haft et valg med hensyn til at stå eller falde, dvs. ingen frihed overhovedet" (Outler $e t$ al. 1991, 14-21, her 16).

24 Se fx. John Wesley, "Original Sin" (1759), Works VI, 43-53.

25 Works VI, 506-513, 512.

26 Se hertil Rakestraw 1984, 193-203. Det skal nævnes, at Wesley nogle gange kan skyde et element af anger, omvendelse eller den overbevisende nåde (convincing grace) ind mellem prevenient grace og justifying grace, fx. Works VI, 509. På samme måde kan Wesley beskrive faldet med en minutiøs interesse for dets enkeltes stadier.

27 Helt samme opfattelse i salmen Det evige Livs-Ord $(G S V$ V, 67) og i Daabs-Pagten (GSV V, 170), særligt strofe 2-4. 
Dette aspekt overses af Christian Thodberg (1989, 7-119) i hans indflydelsesrige arbejde, En glemt dimension $i$ Grundtvigs salmer bundetheden til dåbsritualet. Thodberg mener, at dåbens tilspørgsel: "Tror du på...", slet ikke skal opfattes som et spørgsmål fra Gud til menneske, men som Guds suveræne tilsagn og tiltale: "Det er Gud, der spørger, og det er dermed [sic!] Gud, der giver helt suverænt". Hermed bliver ritualet angiveligt "et markant udtryk for Guds enehandlen" (ibid., 92). Denne tolkning rystes tilsyneladende ikke af, at Grundtvig faktisk siger det stik modsatte i de strofer, som Thodberg selv belægger sin tolkning med: "Lægger du, som Hjertet vil / Ja og Amen dit dertil / Da i Vand med Ord og Aand / Bader dig min høire Haand / Og til Skjønhed over Sky / Fødes du deraf paa ny" (GSV V, 67, 5). Thodberg har, så vidt jeg kan se, intet belæg for den opfattelse, at "Helligånden før dåbshandlingen griber ind og fremkalder det [trospagtens] ja" (93), heller ikke for den gentagne opfattelse, at "[v]ed dåben er Gud helt suveræn, og dåben bliver en ensidig pagt" (95). Thodberg er til syneladende klar over den vanskelighed for hans tolkning, at gudmoderens svar kommer " $\mathrm{i}$ klemme" og at Grundtvig har et "problem", ja en "uklarhed" vedrørende om mennesket selv kan svare ja (92). Det er så meget mere bemærkelsesværdigt, som Thodberg selv citerer den Grundtvigsalme, hvori Grundtvig skriver: "Ja og Amen gaaer i Dands, / Vores Ja og Amen Hans, / Det er reen Aftale!" (GSV V, 274, 2). Som vi snart vil se, har Grundtvig både i salmerne og i Den christelige Børnelcerdom en ganske klar redegørelse for, i hvor høj en grad det naturlige menneske er i stand til at sige ja til Gud før Helligåndens fornyelse af mennesket gennem dåben.

29 Se hertil mit bidrag, "Når der bliver mere ud af mindre: Grundtvigs menneskesyn" (Gregersen 2002, 11-30).

30 Prodiken til 1ste Søndag efter Trinitatis 1855 (Lindhardt 1974, 125-127, her 127). - Jeg er forskningslektor ph.d Kim Arne Pedersen meget taknemmelig for hans henvisninger til denne og andre prædikener, som har vist sig relevante for artiklens tema.

31 Nik. Fred. Sev. Grundtvig, Christelige Prodikener eller Søndags-Bog, III, 203-226.

32 Søndags-Bog III, 213. - Om motivet i øvrigt, se Schjørring 1990, 57-86.

33 Søndags-Bog III, 215.

34 Et eksempel er 1. S. e. Trin. 1836 (Brandt 1875), hvor Grundtvig endnu engang advarer imod at tro, at man kan møde Kristus som frelser i opstandelsens liv, hvis man ikke har villet høre Moses og profeterne (349). Den tydeligste tekst er dog prædikenen til 1. S. e. Trin 1861, som behandles nedenfor.

35 Tanken om den anden chance spillede i øvrigt også en helt central rolle inden for grundtvigianismen i Grundtvigs samtid. Ud fra muligheden for en omvendelse efter døden afviste grundtvigianerne på den ene side påstanden om alle ikke-kristnes sikre fortabelse (en påstand, som var almindelig i de ikke-grundtvigske vækkelsesbevægelser), på den anden side, at alle automatisk bliver frelst til det evige liv. Et førstehåndsindtryk af de 
eskatologiske forestillinger $\mathrm{i}$ den grundtvigske bevægelse får man igennem P. C. Kierkegaards foredrag om apokatastasis (Kierkegaard 1848, sp. 288-304), efterfulgt af referat af diskussionsindlæg (ibid., sp. 304-308). Der fremgår heraf, at der var enkelte røster til fordel for apokatastasis blandt konventets medlemmer, men at både P. C. Kierkegaard og andre grundtvigske ledere gik imod, dels ud fra dåbspagtens forsagelse af Djævelen (der dermed ikke kan frelses), dels ud fra Skriften. Derimod henviser Kierkegaard til den legitime mulighed for at "udvide sit Haab" (290) med henvisning til Herrens nedfart til Helvede, som netop finder sted i "Mellemrummet" mellem den enkeltes død og alle opstandelse til dom (ibid.). Helt centralt står atter tolkningen af dåben som en forkyndelse af det evangelium, der i tidens fylde vil blive tilbudt til alle, men som nogle alligevel ikke tager til sig, men modsætter sig: "Ved Daaben i den Treeniges Navn indpodes den Spire ogsaa i Mange, der ikke tilegne sig den og ikke pleie den, og i sin Bolig, d.e. i Evangeliets Ord, trænger Menneskesønnens Aand fra alle Sider, saavidt og saalænge skee kan, med denne samme Spires Anmeldelser og Varsler ind paa alle dem, hvem Evangeliet nogensinde tilbydes, og det er jo, som vi troe, Alle. Men modsætter et Menneske sig nu, saalænge han overhovedet kan ville, denne Indtrængen af det nye Liv i hans naturlige, qvæler han vel netop den Spire deraf, som i Daaben blev plantet hos ham..." (296 f.) - Eksemplet viser, at den universalistiske frelseskonditionalisme er bygget ind $\mathrm{i}$ den kirkelige anskuelse, ikke alene hos Grundtvig selv, men også hos en så fremtrædende repræsentant for den kirkelige anskuelse som den senere biskop P. C. Kierkegaard.

N. F. S. Grundtvig: "Første Søndag efter Trinitatis 1861" (Sidste Praedikener I, 3).

Prædiken til 1. S. e. Trin. 1869 (Sidste Praedikener II, 194).

Prædiken til 1. S. e. Trin. 1871 (Sidste Prodikener II, 411).

Prædiken til 1. S. e. trin. 1861 (Sidste Proedikener I, 4.)

40

1. S. e. Trin. 1856 (Lindhardt 1977, 112). 